\title{
Collusions In Chinese Family Firms: An Informal Institution-Based View Of Multiple Large Shareholders
}

Huaili Lv, Shanghai University, P. R. China

Wanli Li, Xi'an Jiaotong University \& Shanghai University of Intl. Business and Economics, P. R. China

\begin{abstract}
Informal institutions such as culture is contingent condition affecting opportunism in large shareholders' relationships (Sauerwald and Peng, 2013). Using the data from 2003 to 2012 of Chinese family firms, our research finds that the collusions of multiple large shareholders (MLS) caused by Chinese family-oriented collectivism culture lead to firm's investment inefficiency, including overinvestment and underinvestment. Unlike prior literature focusing merely on the agency problems of management or controlling shareholders, this study provides evidence of the agency problems of MLS. From examining the relations and allocations of shareholders ownership, we provide shareholders' collusions, a new theoretical perspective to explain the investment inefficiency in Chinese family firms.
\end{abstract}

Keywords: Formal Institution; Informal Institution; Multiple Large Shareholders (MLS); Collusions

\section{INTRODUCTION}

$\mathrm{n}$ a world with principal-principal (PP) conflicts, there are agency problems between controlling and minority shareholders. Both formal and informal institutions will affect the conflicts of these two inhospitable groups (Peng and Sauerwald, 2012; Sauerwald and Peng, 2013). Scholars with a formal institution-based view suggest that the PP conflicts could be prevented by or declined with special internal governance mechanisms such as the existence of multiple large shareholders (MLS). They find that MLS plays a potentially restrictive role in alleviating the firm's agency costs and information asymmetry between controlling and minority shareholders (Attig et al., 2013; Attig et al., 2009). Firm's with MLS will (1) generate competition among block holders for control contest (Bloch and Hedge, 2001); (2) stimulate other shareholders' monitoring motivation on the controlling shareholder (Pagano and Roell, 1998); (3) force other shareholders to form the balance of power with controlling shareholder (Bennedsen and Wolfenzon, 2000); (4) mitigate controlling shareholder's moral hazard (Berkman et al., 2009); and finally increase enterprise values (Maury and Pajuste, 2005).

Nevertheless, MLS is not always a good mechanism to protect the interests of minority shareholders. Bennedsen and Wolfenzon (2000) argue that there are coalition formation effects of the large shareholders in firms with PP conflicts. When it's hard for one single shareholder to control the firm, coalescing with other large shareholders will make it easier. In fact, both formal and informal institutions will affect the PP conflicts, and informal institutions are complementary or substitutional with the formal institutions, especially in firms with weak formal institutions (Helmke and Levitsky, 2004). Sauerwald and Peng (2013) pointed out that in emerging economies with relatively underdeveloped formal institutions for shareholders' rights protection, informal institutions will play an important role in corporate governance and affect the PP conflicts.

Social context such as legal origin and culture will affect corporate insiders' private benefit of control. Legal origin has important influence on firm's micro-behaviors such as the arrangement of ownership structure and its economic consequences (La Porta et al., 1998, 1999). However, under a context of poor legal protection and lack of law enforcement, culture often leads to systematic exploitation of the legal vacuum, finally prompte even 
immoral or illegal behaviors (Zhang et al 2013). China, a civil law-dominated country, has established its modern system of property rights at the beginning of the reform and opening up. There are MLS in Chinese firms, especially in firms controlled by family groups. But the history of modern property rights system is merely thirty years. Governed by moralities and ethics of Confucianism for more than two thousand years, most Chinese are collectivism-orientated and lack self-awareness, which is different from Westerners Anglo-Saxons. As a society of collectivism, China is greatly influenced by Confucianism, which stresses the consensus of opinions and encourages coordination. The modern system of property rights in Chinese family firms will show many non-property characteristics such as the existence of informal institutions. And MLS will play some other roles in corporate governance in China, or even ones totally opposite to the west. Simply transplanting formal institutions into another culture will result in weak formal institutions, and the informal institutions shaped by culture may play a central role in the emergence of PP conflicts (Sauerwald and Peng, 2013).

This study contributes to the literature on the role of informal institutions in ownership arrangement and its economic consequence. First, our research reveals collusions are typical features in family firms with MLS. Although prior studies give an explosive attention on ownership structures and its arrangement (Morck et al., 1988; Cho, 1998; Demsetz and Villalonga, 2001), the researches mainly investigate the static arrangement of ownership structure. We broaden the scope of researches of ownership structure on MLS by considering shareholders' relationships caused by family-oriented collectivism culture, an important informal institutions in China. Just as Faccio et al. (2001) argued, the presence of MLS will exacerbate controlling shareholder's expropriation in Asia due to collusion incentive, which will have much difference as depicted in Attig et al. (2009). Second, using a unique data from Chinese family firms, we provide evidence that the informal institutions on MLS will generate poor economic consequence such as investment inefficiency. The research finds that collusions of MLS can lead to firm's investment inefficiency, including overinvestment and underinvestment. This paper broadens the research of informal institutions in emerging economy. Although in formal institutions perspective, family ownership is an effective organizational structure (Anderson and Reeb, 2003), it will play an opposite governance effect in perspective of large shareholders' relationships caused by family-oriented collectivism culture.

The remainder of this paper is organized as follows: section 2 presents the institutional backgrounds in China and Chinese family firms. Section 3 presents theoretical analysis and develops our research hypotheses. Section 4 describes data, variables and research models. Section 5 provides empirical tests and analyses. Section 6 conducts necessary robust test. Sections 7 and 8 conclude this paper and present limitations of our approach and recommendations for future researches.

\section{INSTITUTIONAL BACKGROUNDS}

\section{Types of Family Ownership and PP Conflicts of MLS}

\section{Types of Family Ownership}

Chinese government started the property rights reform at the very beginning of its reform and opening up in late 1970s. Before that, state-owned enterprises (SOEs) were the predominant type of ownership in China. But since then, the significance of SOEs declines steadily, and the proportion of non-SOEs such as family firms is increasing at a rather high rate. After the property rights reform, China established an economic system with state and non-state ownership. Within the economic system, state ownership is the leading factor, while other forms of non-state ownership such as family ownership coexist with it. But interestingly, property rights are more secure in SOEs than in non-SOEs, because government's regulations have been less hostile to SOEs than to non-SOEs (Chen and Qian, 1998). Until now, China still does not have well-specified property rights, and property rights protection in China is also not so good (Hung, 2008).

The property rights reform gives rise to the emergence of family firms, which increasingly become an important economic subject in China. And family ownership promotes rapid development of China's economy. Family firms play a prominent role in boosting economic growth and solving the problem of unemployment, etc. In family firms, the ownership is mainly controlled by family members or family groups. The linkages of family ownership are blood relations, kinships or marriage. Family members can assert identification with kin, hometown, 
school, workplace, sworn brotherhood, and so on (Luo, 2007). Family shareholders also dominate the decisionmaking procedure of firms' major financial behaviors. The ownership and control rights of family firms often rest in the hands of family members. Family groups control a great majority of ownership, and the ownership they control may help them extract self-interests, and finally good for the family groups.

Through the reform of property rights, there are three main types of shares in Chinese family firms, individual shares, corporate shares, and institutional shares. Individual shares are also known as natural person shares, the holders of which in a firm is individuals or natural person. Individual shares are most common stocks in family firms, which also include domestic individual shares and foreign individual shares. Corporate shares are also called legal person shares, the holders of which are companies or legal person. Corporate shareholders can be divided into domestic corporate shares, foreign corporate shares. Domestic corporate shares usually contain stateowned corporate shares and non-state-owned corporate shares. Institutional shares are stocks that are held by institutional investors such as securities, funds, insurances, trusts, and finance companies. In addition, there are also $\mathrm{B}$ shares and $\mathrm{H}$ shares in Chinese family firms. B shares are those held by foreign investors, and traded in foreign currencies in Shanghai and Shenzhen Stock Exchanges. H shares are stocks issued by firms listed in Hong Kong Stock Exchange and are generally held by Hong Kong investors, including individual investors and institutional investors. Figure 1 displays the different types of shares in Chinese family firms. 
Figure 1. Different types of shares in Chinese family firms

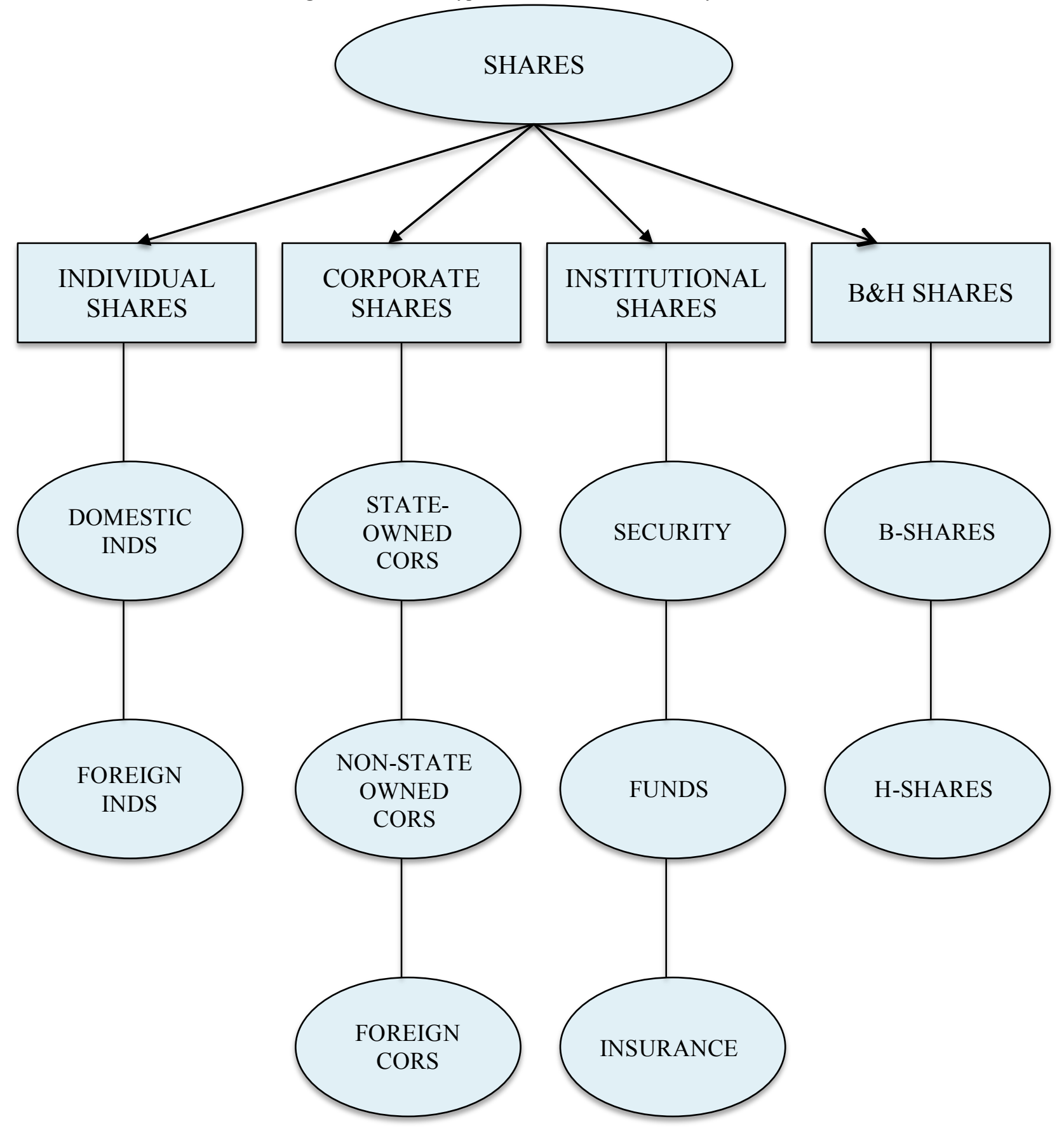

PP Conflicts of MLS

Principle-agent (PA) conflicts between owners and managers and principle-principle (PP) conflicts between controlling and minority shareholders are two predominant models of corporate governance within all national contexts (Young et al., 2008). However, in emerging economies, the PP conflicts are more severe for reason of weak internal governance mechanisms and poor institutional protection of minority shareholders (La Porta et al., 1997). In such emerging economies as China, the ownership is highly concentrated and the divergence between cash-flow 
rights and control rights is large, while PA conflicts are generally limited and PP conflicts are severe (Claessens et al., 2002).

Many researches reveal that family ownership is a major cause of PP conflicts in emerging markets. Family control has two opposite effects on the governance of family firms. On one hand, family control can reduce monitoring costs and mitigate PA conflicts. On the other hand, family control may increase the likelihood of expropriation of non-family minority shareholders by the controlling family groups. In their earlier research of PP conflicts in family firms, Claessens et al. (2000) find that managers of closely held firms tend to be relatives of the controlling shareholder or his family members in East Asian corporations. And managers are usually related to the family groups of the controlling shareholder (Claessens et al., 2002). Chinese family owners also prefer to appoint family members as CEOs to guarantee control and protect the interests of family groups (Cai et al., 2012). Family members as CEOs will make benefit extraction easier and eventually exacerbate the PP conflicts. Hence, in emerging markets with poor protection of minority shareholders, the PA conflicts between managers and owners are usually minor, and the PP conflicts between family and non-family groups are dominant in family-controlled firms.

Multiple large shareholders (MLS) in Chinese family firms are common. According to the statistics in Chen et al. (2009), in Chinese family firms, the average ratio of shares held by controlling shareholder is about $32.14 \%$ and $11.96 \%$ and $5.13 \%$ is held by the $2^{\text {nd }}$ and $3^{\text {rd }}$ largest shareholders, respectively. However, in SOEs controlled by central government, the ownership is more concentrated and the largest shareholder accounts for $51.79 \%$ of issued shares. Literatures on corporate governance finds that MLS can strengthen other large shareholders' monitoring effect on controlling shareholder and shape the ability of MLS to exert governance in Chinese family firms (Luo et al., 2013; Cai et al., 2012). However, many of the researches fail to consider family relations caused by informal institutions such as family-oriented collectivism. Family relations tend to make the PP conflicts more difficult to resolve due to self-control and other problems engendered by altruism among family members (Schulze et al., 2001). Failure to understand the institutional nature of PP conflicts in emerging economies will make corporate governance mechanism irrelevant and counterproductive (Peng et al., 2008).

Despite the co-existence of MLS with various types of shares within Chinese family firms, we don't exactly know the interrelations among holders of individual, corporate and institutional shares. How many forms of interrelations are there between controlling shareholder and other large shareholders? What will influence the interrelations and how to classify them? Will the governance mechanism be changed or reversed when we take the informal institutions into our consideration?

\section{China's Family-Oriented Collectivism Culture and Classification of Large Shareholders}

\section{China's family-oriented collectivism culture}

Institutions are ancient constraints that possess economic behaviors and interactions. They are consist of both formal institutions such as laws, property rights and ownership arrangements, and informal institutions such as cultures, norms and beliefs. (North, 1991). Peng and Heath (1996) suggest that informal institutions arise to play a more important role in driving firm performance in situations where formal institutions are weak. The aim of property rights reform in China is to establish effective formal institutions as in west economies. But things don't turn out the way we want. Merely three decades of reform cannot withstand thousands of years of family-oriented collectivism culture. In China, informal institutions have substitutive features, whereby informal institutions substitute for the ineffective formal institutions (Estrin and Prevezer, 2011).

Sauerwald and Peng (2013) argue that culture is a contingent condition affecting opportunism in large shareholders' relationships, and finally play a central role in the emergence of PP conflicts. In China, the collectivism culture leads to personal relationships. Shapiro et al. (2003) find personal relationships are deeply embedded in Chinese culture, and all social interactions, including business, are carried out via it, primarily within the family network. Close personal relationships are established through families. The family members include not only the father, the mother, siblings, but also other relatives and friends, even those from the same place or having the same dialect. Personal relationships are not so important in Westerners and cannot be understood apart from the 
collectivism culture (Fukuyama, 1995).

In Chinese family firms, the propensity to conduct financial behaviors through informal networks such as personal relationships is a reflection of Chinese family culture. Without a strong reliable formal institutions in Chinese social context, people had to rely more on family members. There exist objectively the dual characteristics of 'family' and 'firm' in Chinese family firms. As a 'family', the run of the family is often irrational (e.g. close knit of blood relationships and maximization of the whole family's interests) and more in line with subjective purpose of family members. Hence, there are two features in Chinese family firms. First, family firms pursue Chinese familyoriented collectivism culture, which is the core value of Confucianism. According to the family-oriented collectivism culture, individuals are fundamentally social or relational beings, and they always view themselves as interdependent with the social context because of the influence of Confucianism (Luo, 2007). Chinese familyoriented collectivism culture advocates cohesion and loyalty within the family network, but discrimination and hostility outside it. Second, the governance of family firms follows the social models of 'father to son' or 'elder to younger'. The sons or the young show great respect for fathers or the old, and absolute obedience to their commands and orders. This constitutes the ethnic features of Chinese family culture. Unfortunately, this may lead to abuse of family rights or corruption among family members.

\section{Classification of Large Shareholders}

In Chinese family firm, large shareholders includes controlling shareholder and non-controlling large shareholders. Controlling shareholder is firm's largest shareholder, and non-controlling large shareholders are the several largest after the controlling shareholder, for example, the $2^{\text {nd }}$ and $3^{\text {rd }}$ or to the $5^{\text {th }}$ largest shareholders (Lv et al., 2012). We divide the controlling and non-controlling large shareholders into three different groups such as family-group shareholders, state-owned shareholders, and institutional-hold shareholders. Family-group shareholders contain the holders of domestic individual shares and of non-state-owned corporate shares. Stateowned shareholders indicate the holders of state-owned corporate shares. Institutional investors and the holders of foreign individual shares, foreign corporate shares, B shares and $\mathrm{H}$ shares are involved in institutional-hold shareholders. Three different dimensions of controlling and non-controlling large shareholders are displayed in Figure 2. 
Figure 2. Three different groups of controlling and non-controlling large shareholders

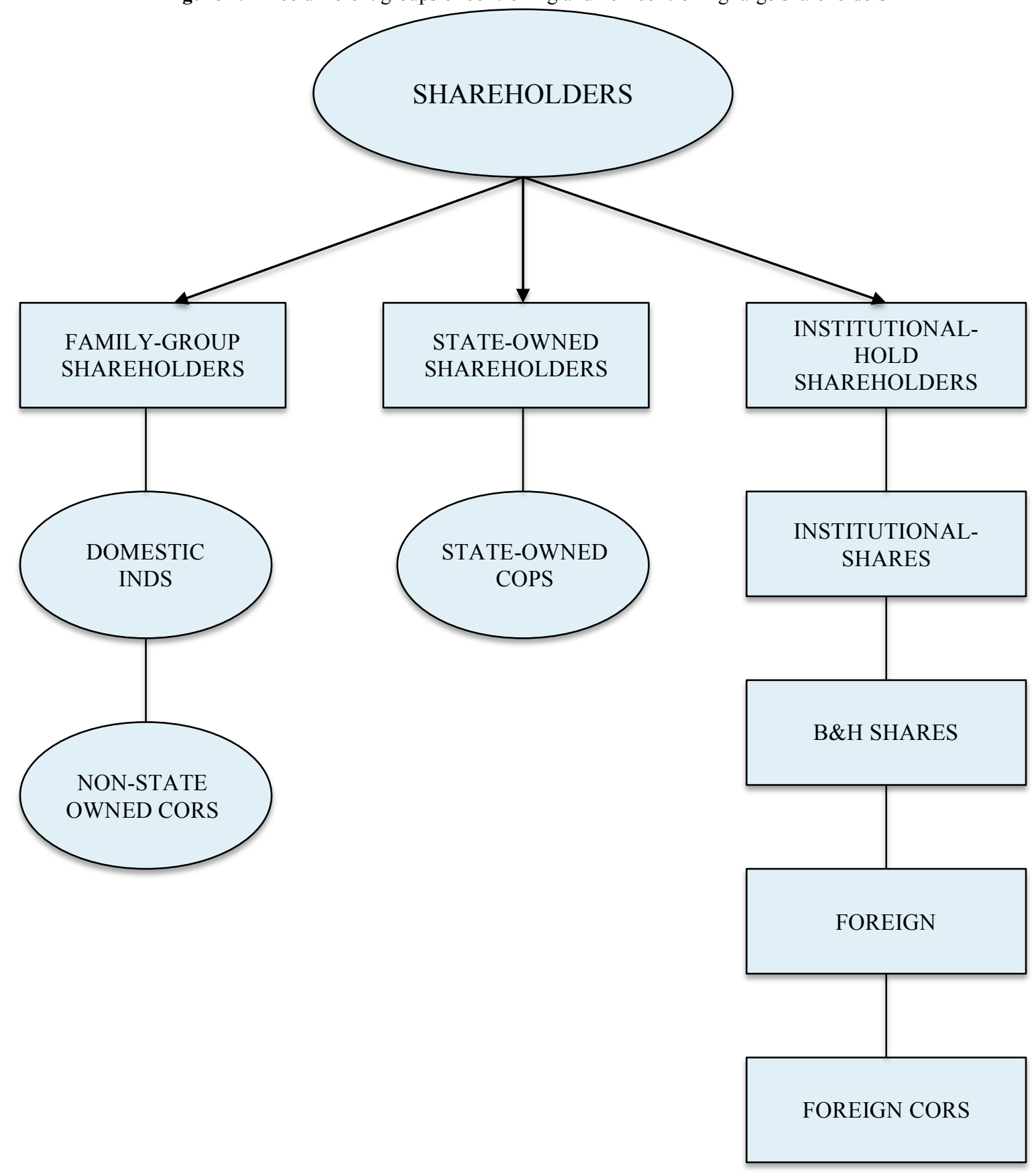

The reasons why we group together the holders of domestic individual shares and of non-state-owned corporate shares is that in Chinese family firms, the former are usually family members and the latter are usually companies controlled by family members or family groups. One example of a family firm that has relations of MLS is Shenzhen Zero-Seven Co., Ltd. (Zero-Seven, henceforth). Zero-Seven is a company of mineral marketing and hotel management, which has been listed on the Shenzhen Stock Exchange (000007.SZ) in 1992. The controlling shareholder of Zero-Seven is a non-state-owned companies, Guangzhou Bo-Rong Investment Co., Ltd. (Bo-Rong Investment, henceforth), holding $17.41 \%$ of total outstanding shares. The $2^{\text {nd }}$ largest shareholder is a domestic individual shareholder Mr. Lian Weifei, the president of the board of Zero-Seven, holding $10.82 \%$ of total outstanding shares. Furthermore, the actual controller of Bo-Rong Investment is Ms. Li Chengbi, the president of the 
board of Bo-Rong Investment and vice-president of the board of Zero-Seven. What's interesting is the personal identity of Ms. Li Chengbi as the mother in law of the $2^{\text {nd }}$ largest shareholder, Mr. Lian Weifei. Although we find the relationship between controlling and the $2^{\text {nd }}$ largest shareholders from the annual reports of Zero-Seven, the relations with the $3^{\text {rd }}$ or other largest shareholders cannot be found directly merely through the information disclosed by Zero-Seven. But culling from media reports, we find the $3^{\text {rd }}$ largest shareholder Mr. Su Guangwei (holds $9.09 \%$ of total outstanding shares) colluded with the $2^{\text {nd }}$ largest shareholder Mr. Lian Weifei to have gained huge private benefits through seasoned equity offering in 2010. In reality, the controlling shareholder Bo-Rong Investment and non-controlling large shareholders Mr. Lian Weifei and Mr. Su Guangwei form a labyrinth of relationships. Some of the relationships can be found directly, but more of them cannot. Figure 3 displays the ownership structure, control map and relations of MLS in Zero-Seven.

Figure 3. Ownership structure, control map and relations of MLS in Zero-Seven (2012)

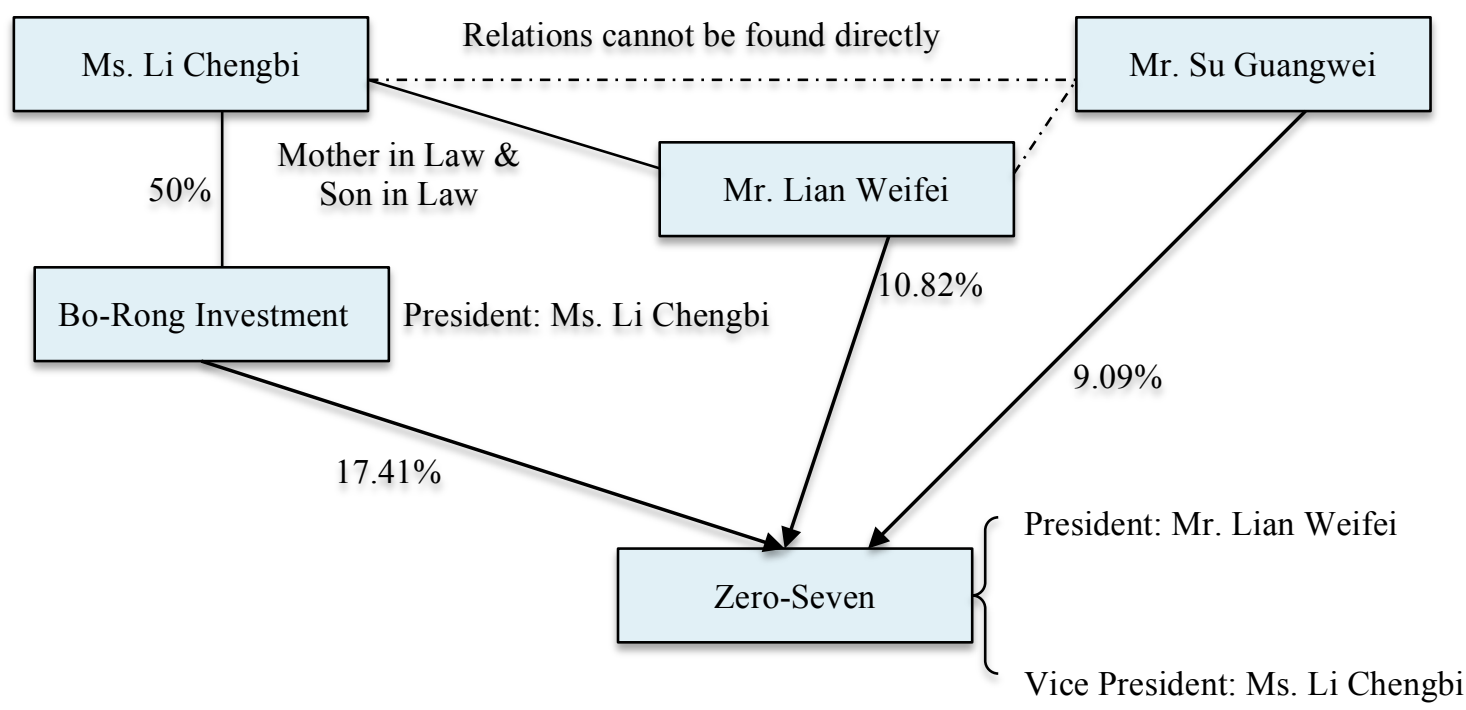

In addition, the other two groups, state-owned shareholders and institutional-hold shareholders, have very different interest orientations and selections with the family-group shareholders. The governance effects of stateowned and institutional-hold shareholders will be influenced by these different interests (Wei et al., 2005). Wei et al. (2005) argue that in Chinese family firms the holders of state-owned legal person shares are more profit-oriented and have more incentives to monitor the firm. As holder of state-owned shares is central or local government, their primary interest may be more political, such as maintaining employment, and relationships would not seem so important as natural person shareholders. Furthermore, many studies reveal that institutional investors and foreign investors have positive effect on corporate governance or play an effective role in monitoring the expropriation of large shareholders (Ferreira and Matos, 2008; Bai et al., 2004).

\section{THEORETICAL ANALYSIS AND RESEARCH HYPOTHESES}

\section{Theoretical Analysis}

As PP conflicts between controlling and minority shareholders, the origination of PP conflicts between large shareholders (controlling shareholder and non-controlling large shareholders) and minority shareholders is also the separation of control rights and cash flow rights. Comparing with the absolute concentration ownership structure in SOEs, we argue that the relatively dispersed ownership structure in family firms increases the complexity of the governance of MLS. Controlling shareholder is no longer absolutely controller, and other large shareholders doesn't take it silently when confronted with controlling shareholder's decision. It is not too easy for controlling shareholder to implement a decision without other large shareholders' help. Hence, there are coalitions among controlling shareholder and non-controlling large shareholders in Chinese family firms. In this paper, we argue the coalitions among large shareholders may be harmful to minority shareholders, or may also be harmless. If the coalitions are no 
harm to the minority shareholders, the coalitions are defined as collaborations. Otherwise, they are defined as collusions. We believe that collusions of MLS occur predominantly in firms with controlling shareholders holding less than $50 \%$ of outstanding shares. The control power of controlling shareholders are too strong when they holds more than $50 \%$ of outstanding shares, they don't need non-controlling large shareholders' collusions to expropriate minority shareholders.

Although PA conflicts are less prevalent in family firms, family control gives rise to PP conflicts, leading to expropriation of the wealth of minority shareholders by family owners particular in legal regimes where the protection of minority shareholders is low (Maury, 2006). Family ownership is the predominant mode of governance in emerging and developing economies, and the weakness of legal system and judicial enforcement make family ties highly significant (Steier, 2009). In family group, the controllers of subsidiaries or sister companies belongs to the same family group, and interlocking networks among family controllers can allow funds to flow quickly into promising new businesses. Hence, the PP conflicts of MLS will let the private benefits of control becomes easier to obtain. The collusions of MLS will give the family controlling group sufficient voting power to control the firm. Maury and Pajuste (2005) suggest that in family-controlled firms there are coalitions among family owners. The incentive to collude or not depends on the type of large shareholders. They assume that the coalition between family members is easy to create and sustain, but a coalition between a family and non-family members might not be that interested in private benefit extraction. Hence, it is important to consider the identities of non-controlling large shareholders when examining the influence of MLS on corporate governance (Cheng et al., 2013).

Collusions will affect firm's performance and eventually harm to minority shareholders. Maury and Pajuste (2005) find that a higher voting rights held by another family owner is negatively related to firm value, whereas a higher voting rights is positively related to firm value if the voting rights were hold by another non-family owner, typically a financial institution. In reality, private benefits of control are larger in collectivist as opposed to individualist cultures, and the PP conflicts are also severe in collectivism cultures (Zhang et al, 2013). In China, the Chinese family-oriented collectivism has negative effects on firm's performance, and Chinese firms have significantly poorer financial performance than their Western counterparts (Li et al., 2000). Using unique data from Chinese market, Cheng et al. (2013) find that firm's value is lower when its non-controlling large shareholders have relations with the controlling shareholder, especially in firms that are controlled by family group.

Although the PP conflicts of MLS will affect firm's performance, we have little evidence of their effects on business strategies such as investment strategy in Chinese family firms. Informal institution such as family-oriented collectivism culture in Chinese societies has a significant influence on the business strategies of Chinese firms, because individuals are likely to stress kinship and friendship in doing business ( $\mathrm{Li}$ et al., 2000). In this paper, we address the following research questions: How does the existence of MLS influence firm's business strategies such as investment strategy when considering the informal institutions in Chinese family firms? Will the non-controlling large shareholders be partners in crime with controlling shareholder? Will the collusions of MLS lead to investment inefficiency in Chinese family firms? The reason that we choose investment strategy in our research is that investment policy meets the purpose of controlling shareholder's empire building (Stulz, 1990) and has the features of collusions among largest shareholders (Pindado et al., 2011).

\section{Research Hypotheses}

We argue that information asymmetry between inside family-groups and outside investors, and PP conflicts of MLS are two key factors that will affect firm's investment. There are two main aspects of information asymmetry between inside family-groups and outside investors, information asymmetry about relationships of inside family members and about investment strategy. For one hand, outside minority investors usually don't know the exact relations between controlling and non-controlling large shareholders. Although information disclosure is required by Chinese laws (Security Law-no. 86, Accounting Standards for Enterprises-no. 36, Administration of Information Disclosure-no. 48), for example, the disclosure of information about related parties and persons acting in concert, the information contains only shares holding by controllers and their near relatives. Other information, such as friend relationships or working relationships, is voluntary or impossible to disclose. The inadequacy of information will eventually lead that minority shareholders cannot fix the actual relationships of MLS in Chinese family firms. For the other, insiders have the private information of investment strategy, while minority outsiders don't have. 
Asymmetric information serves to constrain the investment decision of firms such as pass up positive-NPV investments or accept negative-NPV investments (Myers and Majiluf, 1984). Family firms will disclose significant investment information, but family ties behind the investment are rarely disclosed.

Furthermore, PP conflicts of MLS will let the investments benefit inside family-groups and harm outside minority shareholders. Insiders have a preference for empire building (Stulz, 1990). In Chinese family firms, family controllers will spend the money on investment projects that are beneficial to the family group. In a family conglomerate, family members always control more than one firm, and there is no difficulty for them to transfer the resources from one firm to another. Controlling and non-controlling large shareholders share benefit extraction or expropriation in line with the benefits of the whole family groups will lead to collusions of them. The CEO and other managers are usually family members or have close personal ties with the family groups (Bertrand and Schoar, 2006), so they will accelerate the benefit expropriation behaviors of controlling and non-controlling large shareholders. With the information asymmetry between insiders and outsiders, the benefit expropriation will become easier and more convenient.

Under a context with PP conflict of controlling shareholders, the separation of control rights and cash flow rights can generate incentives to divert resources, and finally leads to non-value maximizing investment (Morck et al., 2005). The inefficient investment is larger in firms in which a controlling shareholder has smaller cash flow rights. Pindado and de la Torre (2009) suggest that overinvestment and underinvestment problems are more likely to happen in firms that large shareholders have the ability to expropriate minority investors. The root of PP conflicts of MLS is also the separation of control rights and cash flow rights. PP conflicts of MLS will make private benefits of control easier to obtain. In a context with PP conflict of MLS, resources are allocated among different groups, especially in firms controlled by firmly members or family groups. Actually the efficient allocation of resources within a group can exacerbate the inefficient allocation of resources across groups (Almeida and Wolfenzon, 2006). Pindado et al. (2011) find in family firm, the family $2^{\text {nd }}$ largest shareholder will collude with the controlling shareholder in investment decision-making process.

With a poor protection of minority shareholders from formal institutions in China, informal institutions play an important role in allocation of resources. The relations caused by Chinese family-oriented collectivism culture, such as kinship, friendship and working relationship are vital in allocation of resources in family firms. In a family conglomerate, the resources are allocated from family firms to family shareholders or to other firms controlled by family members for reason of the collusions of MLS. The inefficient allocation of resources will eventually generate investment inefficiency in Chinese family firms, such as overinvestment and underinvestment. Hence, we present the following Hypothesis H1.

Hypothesis H1. Ceteris paribus, collusions of MLS in Chinese family firms are positively correlated with firm's investment inefficiency.

\section{METHODOLOGY}

\section{Sample and Data}

Our primary data are from China Stock Market and Accounting Research (CSMAR) database for the period 2003 to 2012. The sample includes 3665 firm-year observations for family firms listed on Shanghai and Shenzhen Chinese Stock Exchanges. Controlling shareholders in our sample all hold less than $50 \%$ of outstanding shares, because in firms with controlling shareholder holds more than $50 \%$, non-controlling large shareholders will subordinate to rather than collude with the controlling shareholder. In our empirical study, we winsorize all ratios at the 1st and 99th percentiles to mitigate the influence of extreme observations. 


\section{Measures}

\section{Dependent Variable}

Consistent with prior researches such as Richardson (2006) and Biddle et al. (2009), we measure investment inefficiency as the deviations from expected investment using an investment expectation model that predicts investment as a function of series of variables. The investment expectation model is as follows:

new investment expenditure $=f(X)$

In the investment expectation model, the dependent variable is new investment expenditure, measured as cash payments for fixed assets, intangible assets, and other long-term assets from the cash flow statement minus cash receipts from selling these assets, scaled by initial total assets. The independent variables in the prediction model are: (1)lag value of new investment expenditure, which is used to measure the investment expenditure prior to the investment year; (2)lag value of revenue growth, which is used to measure firm's growth opportunities prior to the investment year; (3)lag value of leverage, which measures the level of short term and long term debt prior to the investment year, deflated by beginning total assets; (4)lag value of cash, which measures the balance of cash and short term investments prior to the investment year, deflated by beginning total assets; (5)lag value of age, which equals the log of the number of years the firm has been listed on Shanghai or Shenzhen Exchange prior to the investment year; (6)lag value of stock returns, which measures firm's stock return prior to the investment year; (7)lag value of size, which equals the log of beginning total assets prior to the investment year; and industry and year dummy variables.

Positive deviation from expected investment is defined as overinvestment (over invest), and negative deviation from expected investment is defined as underinvestment (under invest). Both overinvestment and underinvestment are measures of inefficient investments (invest inefficiency). To ease explanation, we multiply the variable under invest by -1 so that a higher value suggests a more severe underinvestment.

\section{Independent variables}

We first define variable $M L S$ coalition 3 to measure the coalitions of the top3 largest shareholders in Chinese family firms. MLS coalition 3 is calculated as follows:

MLS coalition $3=3 * L_{1}+2 * I^{*} L_{2}+1 * I * L_{3}$

Where Arabic numbers “ 3 ", "2" and" 1 " represent the voting strength of the $1^{\text {st }}, 2^{\text {nd }}$ and $3^{\text {rd }}$ largest shareholders, respectively. Following the oceanic games proposed by Milnor and Shapley (1978), in an oceanic game, voting strength, as measured by the weights of players' value equation, is inhomogeneously distributed and has no effect on the major players. So we use constant figures to represent the voting strength of MLS. $L_{1}, L_{2}$ and $L_{3}$ are ratios of shares holding by the $1^{\text {st }}, 2^{\text {nd }}$ and $3^{\text {rd }}$ largest shareholders, respectively. $L_{1}, L_{2}$ and $L_{3}$ represent the controlling power of top3 largest shareholders. $I$ is a binary variable, which equals one if the $2^{\text {nd }}$ and $3^{\text {rd }}$ largest shareholders belongs to controlling shareholder's family group, and zero otherwise.

According to our theoretical analysis, coalitions include collaborations and collusions. Collusions will harm to minority shareholders, and collaborations are harmless. Hence, we argue that in Chinese family firms, collusions are main factors that cause investment inefficiency, and collaborations have no effect on investment inefficiency. We then build three models to estimate the collusions of the top3 largest shareholders, MLS collusion3, MLS collusion3_O and MLS collusion3_U. The models are as follows:

MLS coalition $3=f(X)$

In the models, the dependent variable is MLS coalition 3 and independent variables are invest inefficiency, or over invest or under invest, respectively. We calculate collaborations as equal to coalitions when there are zero deviations from expected investment, which means there is neither overinvestment nor underinvestment. That is, 
collaborations equal to the intercepts of the estimation model, which are intercept1, or intercept 2 or intercept 3 when the independent variables in the estimation models are invest inefficiency, or over invest or under invest, respectively. In our estimation models, we do our regressions for each industry-year. We finally calculate variables $M L S$ collusion3, $M L S$ collusion3_O and $M L S$ collusion3_U as follows:

$M L S$ collusion $3=M L S$ coalition $3-$ intercept 1

$M L S$ collusion3_O=MLS coalition3-intercept 2

$M L S$ collusion3_U $=$ MLS coalition3-intercept 3

\section{Control Variables}

To be consistent with the literature, our regression model includes four main control variables, industry and year dummies. The four main control variables are monetary policy, free cash flow, control contest, and board size, while monetary policy is macro factor, and the other three variables are micro factors.

Monetary policy is measured as the growth rate of the supply of broad money (M2). Hubbard (1998) argued that contractionary monetary policy can raise the cost of external financing in firms with finance constraints. The investment will fall when firms are in face of contractionary monetary policy, and the finance constraints are not so large when firms are in the context of accommodative monetary policy. Thus, monetary policy affects firm's investment. All else being equal, accommodative monetary policy will lead to firm's overinvestment, and contractionary monetary policy is correlated with underinvestment.

Free cash flow is used to study the effect of firm's operating activities on investment. Following Richardson (2006), we measure free cash flow as cash flow from operating activities, plus research and development expenditure, less reported depreciation and amortization, and less the predicted value of new investment expenditure in investment expectation model. Firms with positive free cash flow are more likely to overinvestment, and firms with negative free cash flow are more likely to underinvestment (Richardson, 2006).

Control contest is used to study the effect of shareholders' governance mechanism on investment. We use $\mathrm{Z}$ index to measure the control contest between controlling and non-controlling large shareholders, and it equals to the ratio of shares holding by the $2^{\text {nd }}$ and $3^{\text {rd }}$ largest shareholders over shares holding by the $1^{\text {st }}$ largest shareholder. To enlarge the variation of the $\mathrm{Z}$ index, following Lv et al. (2012), we use the Herfindahl index to substitute for the numerator and denominator of the Z-index. We predict control contest have negative effect on investment inefficiency.

Board size is used to study the effect of managers' governance mechanism on investment. Board size is measured as the log of the number of directors. The literatures find that large board increases problems of communication and coordination between directors and leads to agency problems. Thus, we predict board size have positive effect on investment inefficiency.

\section{The Model}

We build three regression models to examine the effect of collusions of MLS on investment inefficiency in Chinese family firms. Model 1 is used to investigate the main effect of shareholders' collusions on investment inefficiency; model 2 and model 3 are used to investigate the effects of shareholders' collusions on investment inefficiency in firms with overinvestment and underinvestment, respectively. In model 1, the dependent variable is investment inefficiency, independent variables contain $M L S$ collusion 3 and control variables. In model 2, the dependent variable is over invest, independent variables contain $M L S$ collusion3_O and control variables. In model 3 , the dependent variable is under invest, independent variables contain $M L S$ collusion3_U and control variables.

In addition, we also build three regression through the origin model to investigate the influence of shareholders' collusions on investment inefficiency for reason that we have removed the intercepts when calculating $M L S$ collusion3, MLS collusion3_O and MLS collusion3_U. All of above six models are estimated by OLS with robust standard errors. 


\section{RESULTS}

\section{Descriptive Statistics and Correlation Analysis}

Table 1 presents the descriptive statistics and Spearman correlations for main variables in our sample. We find the mean value of invest inefficiency is 0.0347 , which suggests the investment inefficiency in Chinese family firms are not so large. The investment inefficiency of over invest (mean=0.55) is larger than that of under invest (mean=-0.033). The collusions of the top3 largest shareholders MLS collusion3_U (mean=0.0091) in firms with underinvestment is larger than that in firms with overinvestment, $M L S$ collusion3_O (mean=0.0008).

In correlation analysis, MLS collusion3 and MLS collusion3_U are positively with invest inefficiency $(\mathrm{r}=0.0428$ and $\mathrm{p}<0.01)$ and under invest $(\mathrm{r}=0.045$ and $\mathrm{p}<0.05)$, respectively, suggesting the investment inefficiency in firms with collusions of MLS is low, which preliminarily supports our former hypothesis H1. Control variable free cash flow is negatively with invest inefficiency $(\mathrm{r}=-0.1203, \mathrm{p}<0.01)$, over invest $(\mathrm{r}=-0.045, \mathrm{p}<0.1)$, under invest $(\mathrm{r}=-0.1815, \mathrm{p}<0.01)$, which shows significant negative influence of firm's free cash flow. Furthermore, the significantly and negatively correlation coefficients between MLS collusion 3 and control contest $(\mathrm{r}=-0.2169$, $\mathrm{p}<0.01$ ) reveal the validity of our measure of collusions of MLS. In firms with higher control contest among large shareholders, the collusions within them will lower, and vice versa.

Table 1. Descriptive Statistics and Correlations

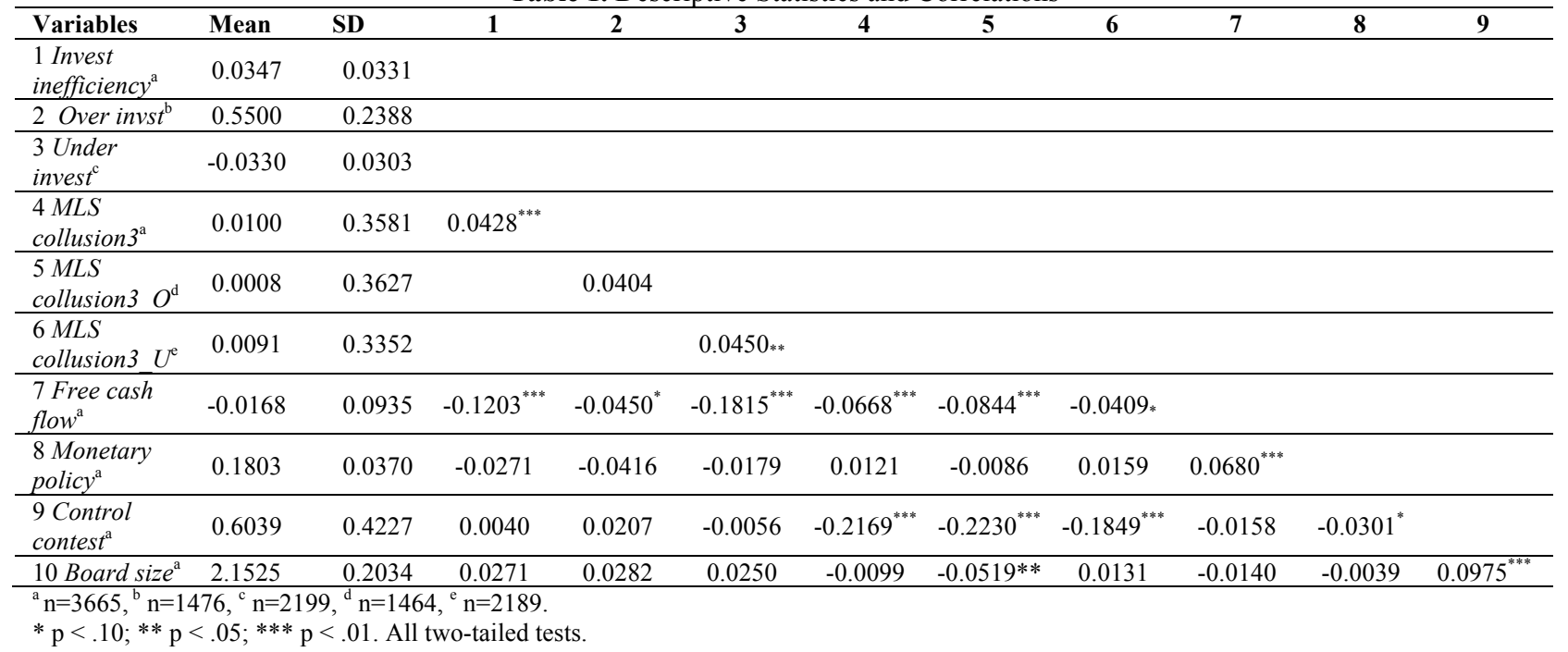

\section{Regression Results}

Table 2 reports the regression results of investment inefficiency (including overinvestment and underinvestment) on the collusions of MLS, which explores the influence of top3 largest shareholders' collusions on investment in Chinese family firms. In regression with intercept models, model 1 shows that MLS collusion 3 is positively and significantly related to investment inefficiency $(\beta=0.0038, \mathrm{p}<0.01)$, supporting hypothesis H1. In model 2 and model 3, the coefficients of MLS collusion3_O and MLS collusion3_U are both significantly positive at the level of 0.05 , which means the collusions of MLS have positive effects on over invest and under invest. The result suggests that Chinese collectivism culture will affect the opportunism in large shareholders' relationships, and finally play an important role in the emergence of PP conflicts of MLS in Chinese family firms.

In regression through origin models, we get the same results as in regression with intercept models. The coefficients of $M L S$ collusion3, MLS collusion3_O and $M L S$ collusion3_U are significantly positive with dependent variables investment inefficiency, over invest and under invest, respectively. Hypothesis $\mathrm{H} 1$ also supported by the regression results in model 1', model 2' and model 3'. Furthermore, the F-value and Adj- $\mathrm{R}^{2}$ in model 1' (F=809.25, Adj- $\left.\mathrm{R}^{2}=0.5284\right)$, model 2' $\left(\mathrm{F}=291.86\right.$, Adj- $\left.\mathrm{R}^{2}=0.5011\right)$ and model 3' $\left(\mathrm{F}=729.89\right.$, Adj- $\left.\mathrm{R}^{2}=0.6359\right)$ are larger than that 
in model $1\left(\mathrm{~F}=10.34\right.$, Adj- $\left.\mathrm{R}^{2}=0.016\right)$, model $2\left(\mathrm{~F}=5.51\right.$, Adj- $\left.\mathrm{R}^{2}=0.0156\right)$ and model $3\left(\mathrm{~F}=8.16\right.$, Adj- $\left.\mathrm{R}^{2}=0.0208\right)$, suggesting the goodness of fit in regression through origin models is better than that in regression with intercept models. The regression through origin models are more appropriate to test our research hypothesis when the intercept is removed in calculating MLS collusion3, MLS collusion3_O and MLS collusion3_U.

The regression results of control variables shown in Table 2 reveal negative coefficients of free cash flow, which suggests that the investment in Chinese family firms the overinvestment or underinvestment doesn't refer to firms' free cash flow. There may be underinvestment even if firms have sufficient cash flow, and vice versa. Monetary policy has negative influence on over invest $(\beta=-0.0643$ in Model $2, p<0.01)$ and positive influence on under invest $(\beta=0.0293$ in Model 3', $\mathrm{p}<0.05$ ), suggesting the contractibility of monetary policy. Non-significant coefficients of control contest suggest that in Chinese family firm with collusions of MLS, the investment inefficiency isn't directly influenced by control contest between controlling and non-controlling large shareholders. The significantly positive coefficients of board size suggest firms with larger board size are more likely to investment inefficiency, including overinvestment or underinvestment.

Table 2. Collusions of top3 largest shareholders and investment inefficiency

\begin{tabular}{|c|c|c|c|c|c|c|}
\hline & \multicolumn{3}{|c|}{ Regression with intercept models (OLS) } & \multicolumn{3}{|c|}{ Regression through origin models (OLS) } \\
\hline & Model 1 & Model 2 & Model 3 & Model 1' & Model 2' & Model 3' \\
\hline Intercept & $\begin{array}{c}0.0274 * * * \\
(4.64)\end{array}$ & $\begin{array}{c}0.0264 * * * \\
(2.72)\end{array}$ & $\begin{array}{c}0.0206^{* * *} \\
(3.67)\end{array}$ & & & \\
\hline MLS collusion 3 & $\begin{array}{c}0.0038^{* * *} \\
(2.54)\end{array}$ & & & $\begin{array}{c}0.0040 * * * \\
(2.63)\end{array}$ & & \\
\hline MLS collusion3_O & & $\begin{array}{c}0.0031^{* *} \\
(2.47)\end{array}$ & & & $\begin{array}{c}0.0033^{* *} \\
(2.56)\end{array}$ & \\
\hline MLS collusion3_U & & & $\begin{array}{c}0.0034 * * \\
(2.22)\end{array}$ & & & $\begin{array}{c}0.0034^{* *} \\
(2.23)\end{array}$ \\
\hline Free cash flow & $\begin{array}{c}-0.0397 * * * \\
(-6.04)\end{array}$ & $\begin{array}{c}-0.0259 * * \\
(-2.17)\end{array}$ & $\begin{array}{c}-0.0306^{* * *} \\
(-5.74)\end{array}$ & $\begin{array}{c}-0.0410 * * * \\
(-6.22)\end{array}$ & $\begin{array}{c}-0.0257^{* *} \\
(-2.15)\end{array}$ & $\begin{array}{c}-0.0323 * * * \\
(-6.07)\end{array}$ \\
\hline Monetary policy & $\begin{array}{c}-0.0150 \\
(-1.06)\end{array}$ & $\begin{array}{c}-0.0645^{* * *} \\
(-2.73)\end{array}$ & $\begin{array}{c}0.0086 \\
(0.65)\end{array}$ & $\begin{array}{c}0.0122 \\
(0.97)\end{array}$ & $\begin{array}{c}-0.0386^{*} \\
(-1.82)\end{array}$ & $\begin{array}{c}0.0293^{* *} \\
(2.47)\end{array}$ \\
\hline Control contest & $\begin{array}{c}0.0003 \\
(0.20)\end{array}$ & $\begin{array}{c}0.0000 \\
(0.01)\end{array}$ & $\begin{array}{c}-0.0002 \\
(-0.17)\end{array}$ & $\begin{array}{c}0.0006 \\
(0.50)\end{array}$ & $\begin{array}{c}0.0004 \\
(0.16)\end{array}$ & $\begin{array}{c}0.0001 \\
(0.08)\end{array}$ \\
\hline Board size & $\begin{array}{c}0.0043^{*} \\
(1.75)\end{array}$ & $\begin{array}{c}0.0108 * * * \\
(2.66)\end{array}$ & $\begin{array}{c}0.0026 \\
(1.10)\end{array}$ & $\begin{array}{c}0.0145^{* * *} \\
(12.79)\end{array}$ & $\begin{array}{c}0.0207 * * * \\
(10.44)\end{array}$ & $\begin{array}{c}0.0103 * * * \\
(9.83)\end{array}$ \\
\hline$F$-value & $10.34 * * *$ & $5.82 * * *$ & $8.16^{* * *}$ & $809.25 * * *$ & $290.15^{* * *}$ & $729.89 * * *$ \\
\hline No.(firm-year) & 3665 & 1464 & 2086 & 3665 & 1464 & 2086 \\
\hline$A d j-R^{2}$ & 0.0147 & 0.0111 & 0.0185 & 0.5277 & 0.4995 & 0.6386 \\
\hline
\end{tabular}

T-values are in parentheses. ${ }^{*} \mathrm{p}<.10 ; * * \mathrm{p}<.05 ; * * * \mathrm{p}<.01$. All two-tailed tests.

\section{ROBUSTNESS}

We build new variables $M L S$ collusion5, MLS collusion5_O and $M L S$ collusion5_U to test the influence of the collusions of top5 largest shareholders on investment inefficiency in Chinese family firms. The calculation method of MLS collusion5 is the same as MLS collusion3, which equals to the coalitions of the top5 largest shareholders (MLS coalition5) minus intercept term from an estimation model. In the estimation model, the dependent variable is $M L S$ coalition 5 and independent variable is invest inefficiency. The calculation of $M L S$ coalition 5 is as follows:

MLS coalition $5=5 * L_{1}+4 * I * L_{2}+3 * I * L_{3}+2 * I * L_{4}+1 * I * L_{5}$

Where Arabic numbers " 5 " to " 1 " represents the voting strength of $1^{\text {st }}$ largest shareholder to the $5^{\text {th }}$ largest shareholder, respectively. $L_{1}$ to $L_{5}$ are ratios of shares holding by $1^{\text {st }}$ largest shareholder to $5^{\text {th }}$ largest shareholder, respectively. The calculation method of MLS collusion5_O and MLS collusion5_U is also the same as MLS collusion3_O and MLS collusion3_U. 
The regression results of the collusions of top5 largest shareholders and investment inefficiency are listed in Table 3. Model 1 to model 3 are regression with intercept models, and model 1' to model 3 ' are regression through origin models. In model 1 and model 1', the dependent variable is investment inefficiency, independent variables contain MLS collusion5 and control variables. In model 2 and model 2', the dependent variable is over invest, independent variables contain $M L S$ collusion5_O and control variables. In model 3 and model 3', the dependent variable is under invest, independent variables contain $M L S$ collusion5_U and control variables.

According to Table 3, OLS estimation of the six models get same results as in Table 2, and the goodness of fit in regression through origin models is better than that in regression with intercept models. To be specific, $M L S$ collusion 5 is positively and significantly related with investment inefficiency in model 1 ( $\beta=0.0022, \mathrm{p}<0.05$, Adj$\left.\mathrm{R}^{2}=0.0156\right)$ and model 1' $\left(\beta=0.0023, \mathrm{p}<0.05\right.$, Adj- $\left.\mathrm{R}^{2}=0.5261\right), M L S$ collusion5_O is positively and significantly related with over invest in model $2\left(\beta=0.0013, \mathrm{p}<0.01\right.$, Adj- $\left.\mathrm{R}^{2}=0.0108\right)$ and model $2^{\prime}(\beta=0.0014, \mathrm{p}<0.01$, Adj$\left.\mathrm{R}^{2}=0.4989\right)$, and $M L S$ collusion5_U is also positively and significantly related with under invest in model 3 ( $\beta=$ 0.0023, $\mathrm{p}<0.01$, Adj- $\left.\mathrm{R}^{2}=0.0195\right)$ and model 3' $\left(\beta=0.0023, \mathrm{p}<0.01\right.$, Adj- $\left.\mathrm{R}^{2}=0.6390\right)$. The results suggest that the collusions of top5 largest shareholders have positive effects on firm's investment inefficiency, which also supporting hypothesis H1. In Chinese family firms, informal institution such as family-oriented collectivism culture will affect the PP conflicts of MLS.

Table 3. Collusions of top5 largest shareholders and investment inefficiency

\begin{tabular}{|c|c|c|c|c|c|c|}
\hline & \multicolumn{3}{|c|}{ Regression with intercept models (OLS) } & \multicolumn{3}{|c|}{ Regression through origin models (OLS) } \\
\hline & Model 1 & Model 2 & Model 3 & Model 1' & Model 2' & Model 3' \\
\hline Intercept & $\begin{array}{c}0.0275^{* * *} \\
(4.63)\end{array}$ & $\begin{array}{c}0.0262 * * * \\
(2.69)\end{array}$ & $\begin{array}{c}0.0206 * * * \\
(3.68)\end{array}$ & & & \\
\hline MLS collusion 3 & $\begin{array}{c}0.0022 * * \\
(2.37)\end{array}$ & & & $\begin{array}{c}0.0023 * * \\
(2.46)\end{array}$ & & \\
\hline MLS collusion3_O & & $\begin{array}{c}0.0013 * * * \\
(2.75) \\
\end{array}$ & & & $\begin{array}{c}0.0014 * * * \\
(2.81)\end{array}$ & \\
\hline MLS collusion3_U & & & $\begin{array}{c}0.0023 * * * \\
(2.67) \\
\end{array}$ & & & $\begin{array}{c}0.0023 * * * \\
(2.66)\end{array}$ \\
\hline Free cash flow & $\begin{array}{c}-0.0413 * * * \\
(-6.17)\end{array}$ & $\begin{array}{c}-0.0259^{* *} \\
(-2.16)\end{array}$ & $\begin{array}{c}-0.0304 * * * \\
(-5.72)\end{array}$ & $\begin{array}{c}-0.0426^{* * *} \\
(-6.35)\end{array}$ & $\begin{array}{c}-0.0257 * * \\
(-2.14)\end{array}$ & $\begin{array}{c}-0.0321 * * * \\
(-6.04)\end{array}$ \\
\hline Monetary policy & $\begin{array}{c}-0.0141 \\
(-0.99) \\
\end{array}$ & $\begin{array}{c}-0.0637 * * * \\
(-2.68) \\
\end{array}$ & $\begin{array}{c}0.0084 \\
(0.63) \\
\end{array}$ & $\begin{array}{c}0.0133 \\
(1.05) \\
\end{array}$ & $\begin{array}{c}-0.0379^{*} \\
(-1.78)\end{array}$ & $\begin{array}{c}0.0291^{* *} \\
(2.45)\end{array}$ \\
\hline Control contest & $\begin{array}{c}0.0006 \\
(0.57) \\
\end{array}$ & $\begin{array}{c}0.0008 \\
(0.46) \\
\end{array}$ & $\begin{array}{c}-0.0001 \\
(-0.09) \\
\end{array}$ & $\begin{array}{c}0.0009 \\
(0.85) \\
\end{array}$ & $\begin{array}{c}0.0011 \\
(0.59) \\
\end{array}$ & $\begin{array}{c}0.0002 \\
(0.18) \\
\end{array}$ \\
\hline Board size & $\begin{array}{c}0.0041^{*} \\
(1.67) \\
\end{array}$ & $\begin{array}{c}0.0105^{* * *} \\
(2.59)\end{array}$ & $\begin{array}{c}0.0025 \\
(1.09) \\
\end{array}$ & $\begin{array}{c}0.0143 * * * \\
(12.57)\end{array}$ & $\begin{array}{c}0.0203 * * * \\
(10.23)\end{array}$ & $\begin{array}{l}0.0102 \\
(9.79) \\
\end{array}$ \\
\hline$F$-value & 10.78 & 6.13 & 8.64 & 804.35 & 289.01 & 730.99 \\
\hline No.(firm-year) & 3665 & 1460 & 2086 & 3665 & 1460 & 2086 \\
\hline $\operatorname{Adj}-R^{2}$ & 0.0156 & 0.0108 & 0.0195 & 0.5261 & 0.4989 & 0.6390 \\
\hline
\end{tabular}

T-values are in parentheses. ${ }^{*} \mathrm{p}<.10 ; * * \mathrm{p}<.05 ; * * * \mathrm{p}<.01$. All two-tailed tests.

\section{DISCUSSION}

In situations where formal institutions are weak, informal institutions such as collectivism culture will play a more important role in driving personal networks and relationships (Peng and Heath, 1996). In this paper, we depict a scenario where non-controlling large shareholders have incentive to collude with the controlling shareholder in Chinese family firms. We study the effect of informal institutions on investment efficiency using the data from 2003 to 2012 of Chinese family firms. We find that the collusions of MLS can lead to firm's investment inefficiency, such as overinvestment and underinvestment. Our research reveals that ownership structures with MLS exacerbate agency problems when taking the family ties and relations that are caused by informal institutions sun as Chinese family-oriented collectivism culture into consideration. 
In practical work, our research will provide a new perspective for the protection of minority shareholders. In Chinese family firms, non-controlling large shareholders will collaborate or collude with the controlling shareholder in firms with MLS. The collaborations will good for (at least no harm to) the benefits of minority shareholders, but the collusions will harm them. Current researches just reveal positive effects such as collaborations of MLS on corporate governance. But there was no getting away from the fact that there were negative effects of MLS on corporate governance. Thus, maybe it doesn't work when blindly emphasizing to build ownership structures with MLS in Chinese family firms. The ties and relations among family shareholders will let the governance mechanisms of MLS become invalid. In practice, policymakers should not only focus on the formal institutions of MLS such as the balance mechanisms of controlling and non-controlling large shareholders, but also the relationships of them.

\section{LIMITATIONS AND FUTURE RESEARCH}

As an exploratory research in the field of informal institutions of MLS, we argue that our study may have several limitations that future research should address. First, there will be some other more detailed classifications on the controlling and non-controlling large shareholders in Chinese family firms, such as directly categorize them into different groups according to kinship, friendship and working relationship. Future researches should calculate the collusions of MLS according to more detailed classifications. Second, the categorisation of any corporate shareholders among family-group shareholders ex-ante eliminates any possibility of their independence. Although the collaboration to a certain extent can reflect the independence of family-group shareholders, it is possible to imagine that there are two large family groups compete for the ownership of a company. Future researchers should take the competition into consideration when calculating the collusions of MLS. Third, we didn't explore the collusions between family shareholders and non family shareholders. Under particular circumstances, there will be collusions between family and non family shareholders such as institutional shareholders (Hou et al., 2011). Future studies should address the relations and tie of family and non-family shareholders.

\section{AUTHOR INFORMATION}

Huaili Lv is an assistant professor of accounting in School of Management at Shanghai University. His main research interests include corporate governance and financial innovation. Huaili Lv, Mailing address: Room 412, Shangda Road 599, Shanghai, 200444, P.R. China. E-mail: 1vhuaili@shu.edu.cn

Wanli Li is a professor of accounting in the School of Management at Xi'an Jiaotong University and School of Accounting at Shanghai University of International Business and Economics. Her main research interests include accounting restatements, earnings management, corporate governance and political connections. Wanli Li, Mailing address: No.28, Xianning West Road, Xi’an, Shaanxi, 710049, P.R. China. E-mail: 1wlxjtu@126.com

\section{ACKNOWLEDGEMENTS}

The authors acknowledge financial support from the National Nature Science Foundation of China [no. 71202043], National Social Science Foundation of China [no. 10BJL014], and Ministry of Education Research of Humanities and Social Science Foundation of China [no. 14XJC790001].

\section{REFERENCES}

Almeida, H. V., and Wolfenzon, D. 2006. A Theory of Pyramidal Ownership and Family Business Groups. The Journal of Finance, 61(6): 2637-2680.

Anderson, R. C. and Reeb, D. M., 2003, Founding-Family Ownership and Firm Performance: Evidence from the S\&P 500, The Journal of Finance, 58(3): 1301-1328.

Attig, N., El Ghoul S., \& Guedhami, O. 2009. Do Multiple Large Shareholders Play a Corporate Governance Role? Evidence from East Asia. Journal of Financial Research, 32(4): 395-422.

Attig, N, El Ghoul, S., Guedhami, O., and Rizeanu S. 2013. The Governance Role of Multiple Large Shareholders: Evidence from the Valuation of Cash Holdings. Journal of Management and Governance, 17(2): 419-451.

Bai, C. E. Liu, Q. Lu, J. Song, F. M., \& Zhang, J. X.2004. Corporate governance and market valuation in China. 
Journal of Comparative Economics, 32(4): 599-616.

Bennedsen, M., and Wolfenzon, D. 2000. The Balance of Power in Closely Held Corporations. Journal of Financial Economics, 58(1-2): 113-139.

Berkman, H., Cole, R. A., and Fu, L. J. 2009. Expropriation through Loan Guarantees to Related Parties: Evidence from China. Journal of Banking and Finance, 33(1): 141-156.

Bertrand, M. and Schoar, A. 2006. The Role of Family in Family Firms. The Journal of Economic Perspectives, 20(2): 73-96.

Biddle, G. C., Hilary, G., \& Verdi, R. S. 2009.How does financial reporting quality relate to investment efficiency? Journal of Accounting and Economics, 48(2-3): 112-131.

Bloch, F., and Hege, U. 2001. Multiple Shareholders and Control Contest. HEC School of Management, Working paper.

Cho, M. H. 1998. Ownership Structure, Investment, and the Corporate Value: An Empirical Analysis. Journal of Financial Economics, 47(1): 103-121.

Demsetz, H. and Lehn, K. 1985. The structure of Corporate Ownership: Causes and Consequences. Journal of Political Economu. 93(6): 1155-1177.

Cai, D., Luo, J. H., and Wan, D. F. 2012. Family CEOs: Do they benefit firm performance in China? Asia Pacific Journal of Management, 29(4): 923-947.

Chen, G., Firth, M., and Xu, L. 2009. Does the type of ownership control matter? Evidence from China's listed companies. Journal of Banking and Finance 33, no. 1: 171-81.

Chen, J. H., Qian Y. Y. 1998. Insecure Property Rights and Government Ownership of Firms. Quarterly Journal of Economics, 113(2): 467-496.

Cheng, M. Y, Lin, B. X and Wei, M. H. 2013. How does the relationship between multiple large shareholders affect corporate valuations? Evidence from China. Journal of Economics and Business, 70(11): 43-70.

Claessens, S., Djankov, S., and Lang, L. H. P. 2000. The separation of ownership and control in East Asian corporations. Journal of Financial Economics, 58(1-2): 81-112.

Claessens, S., Djankov, S., Fan, J., and Lang, L. 2002. Disentangling the incentive and entrenchment effects of large shareholdings. Journal of Finance 57, 2741-2771.

Estrin, S., and Prevezer, M. 2011. The role of informal institutions in corporate governance: Brazil, Russia, India, and China compared. Asia Pacific Journal of Management, 28(1): 41-67.

Ferreira, M. A. and Matos, P. 2008. The colors of investors' money: The role of institutional investors around the world. Journal of Financial Economics, 88(3): 499-533.

Fukuyama, F. 1995. Trust: The social virtues and the creation of prosperity. New York: Free Press.

Faccio, M., Lang, L. H. P., Young, L, 2001. Dividends and Expropriation. The American Economic Review, 91(1): 54-78.

Helmke, G., and Levitsky, S. 2004.Informal Institutions and Comparative Politics: A Research Agenda. Perspectives on Politics, 2(4): 725-740

Hou, Q. C, Jin, Q. L., and Yu, V. C. 2011.Fund Governance and Collusion with Controlling Shareholders: Evidence from Non-tradable Shares Reform in China. Shanghai University of Finance and Economics, Working paper.

Huang, Y. S. 2008. Capitalism with Chinese Characteristics: Entrepreneurship and the State s (1st edition). New York: Cambridge University Press

Hubbard, R.G. 1998. Capital-Market Imperfections and Investment. Journal of Economic Literature, 36(1): 193-225.

La Porta, R., Lopez-de-Silanes, F. and Shleifer, A. 1997. Legal determinants of external finance. Journal of Finance, $52,1131-50$.

La Porta, R., Lopez-de-Silanes, F., and Shleifer, A. 1999. Corporate ownership around the world. Journal of Finance, 54(2): 471-517.

La Porta, R., Lopez-de-Silanes, F., Shleifer, A., and Vishny, R. W. 1998. Law and finance. Journal of Political Economy, 106(6): 1113-1155.

Li, J., Lam, K. and Fu, P. P. 2000. Family-Oriented Collectivism and Its Effect on Firm Performance: A Comparison Between Overseas Chinese and Foreign Firms in China. The International Journal of Organizational Analysis, 8(4): 364-379.

Luo Y. D. 2007. Guanxi and business (2nd edition). Singapore: World Scientific.

Luo, J. J., Wan, D. F., Cai, D., and Liu, H. 2013. Multiple Large Shareholder Structure and Governance: The Role of Shareholder Numbers, Contest for Control, and Formal Institutions in Chinese Family Firms. 
Management and Organization Review, 9(2): 265-294.

Lv, H., Li, W., and Gao, S. 2012. Dividend Tunneling and Joint Expropriation: Empirical Evidence from China's Capital Market. The European Journal of Finance, 18(3-4): 369-392.

Maury, B. 2006. Family ownership and firm performance: Empirical evidence from Western European corporations, 12(2): 321-341.

Maury, B., and Pajuste, A. 2005. Multiple Large Shareholders and Firm Value. Journal of Banking and Finance, 29(7): 1813-1834.

Milnor, J. W., and Shapley, L. S. 1978. Values of Large Games, II: Oceanic Games. Mathematics of Operations Research, 3(4): 290-307.

Morck, R., Wolfenzon, D. and Yeung, B. 2005. Corporate governance, economic entrenchment, and growth. Journal of Economic Literature, 43(3): 655-720.

Morck, R., Shleifer, A. and Vishny, R., 1988, Management ownership and market valuation: An empirical analysis, Journal of Financial Economics, 20 (1-2): 293-315.

Myers, S. C., and Majluf, N. S. 1984. Corporate Financing and Investment Decisions When Firms Have Information That Investors Do Not Have. Journal of Financial Economics, 13(2): 187-221.

North, D.C. 1991. Institutions. The Journal of Economic Perspectives, 5(1): 97-112.

Pagano, M., and Roell, A. 1998. The Choice of Stock Ownership Structure: Agency Costs, Monitoring, and the Decision to Go Public. Quarterly Journal of Economics, 113(1): 187-225.

Peng, M. W. and Heath, P. S. 1996. The Growth of the Firm in Planned Economies in Transition: Institutions, Organizations, and Strategic Choice. The Academy of Management Review, 21(2): 492-528.

Peng, M. W., Wang, D. Y. L., and Jiang, Y. 2008. An institution-based view of international business strategy: A focus on emerging economies. Journal of International Business Studies, 39(5): 920-936.

Peng, M. W., and Sauerwald, S. 2012. Principal-principal conflicts. In M. Wright, D. S. Siegel, K.

Pindado, J., and de la Torre, C. 2009. Effect of ownership structure on underinvestment and overinvestment: empirical evidence from Spain. Accounting and Finance, 49(2): 363-383.

Pindado, J., \& Requejo, L., and de la Torre, C. 2011. Family control and investment-cash flow sensitivity: Empirical evidence from the Euro zone. Journal of Corporate Finance, 17(5): 1389-1409.

Richardson, S. 2006. Over-investment of Free Cash Flow. Review of Accounting Studies, 11(2-3): 159-189.

Sauerwald, S. and Peng, M.W. 2013. Informal institutions, shareholder coalitions, and principal-principal conflicts. Asia Pacific Journal of Management, 30(3): 853-870.

Schulze, W. S., Lubatkin, M. H., Dino, R. N., and Buchholtz, A. K. 2001. Agency relationships in family firms: Theory and evidence. Organizational Science, 12(2): 99-116.

Shapiro, D.M., Gedajlovic, E., and Erdener, C. 2003. The Chinese Family Firm as a Multinational Enterprise. The International Journal of Organizational Analysis, 11(2): 105-122.

Stulz, R. M. 1990. Managerial Discretion and Optimal Financing Policy. Journal of Financial Economics, 26(1): 327.

Wei, Z. B., Xie, F.X. and Zhang, S. R. 2005. Ownership Structure and Firm Value in China's Privatized Firms: 1991-2001. Journal of Financial and Quantitative Analysis, 40(1): 87-108

Young, M.Y., Peng, M. W., Ahlstrom, D., Bruton, G. D., and Jing, Y. 2008. Corporate Governance in Emerging Economies: A Review of the Principal-Principal Perspective. Journal of Management Studies, 45(1): 196220.

Zhang, X., Liang, X., and Sun, H.Y., 2013. Individualism-Collectivism, Private Benefits of Control, and Earnings Management: A Cross-Culture Comparison. Journal of Business Ethics, 114(4): 655-664. 